\title{
Job Design of the Kleder in Cattle Distribution Chain on the Camara Nusantara Cattle Ship
}

\author{
Zulhijariyanto $^{1 *}$, Asnath Maria Fuah ${ }^{1}$, Lucia Cyrilla ${ }^{1}$, Yunus Triyonggo ${ }^{2}$ \\ ${ }^{1}$ IPB University (Bogor Agricultural University) \\ ${ }^{2}$ Bridgestone Tire Indonesia Ltd \\ *Corresponding Author: riyan.zul@gmail.com
}

\begin{tabular}{llll} 
Article history & & & \\
\hline Received & Received in revised form & Accepted & Available online \\
02 August 2019 & 28 August 2019 & 24 November 2019 & 01 December 2019 \\
\hline
\end{tabular}

\begin{abstract}
The governments try to support the distribution of livestock in Indonesia by implementing the sea toll program. The sea toll program is a program implemented to strengthen the logistics system through waterways in Indonesia. The Camara Nusantara Livestock Cattle Ship is part of the implementation of the sea toll program to increase cattle distribution from central regions of beef cattle such as NTB, NTT, and South Sulawesi. The purpose of this study was to analyze and design the design of the kleder work on cattle transportation in the Camara Nusantara Livestock Ship. This study uses descriptive qualitative analysis method by conducting observations, documentation, literature studies, and direct interviews with the objects studied in the field. Primary data is obtained from the main actors and secondary data through observation, documentation, and literature. The work design was designed following the Mader-Clark approach and the cattle distribution chain was presented in the form of a flow chart. Based on the results of this study indicate that the kleder in the Camara Nusantara Livestock Ship does not yet have a design work and has not applied the job description and specifications of the work needed. This is indicated by the absence of work competency standards which are used as work guidelines so that the team does not carry out duties in accordance with their duties and authority on the Camara Nusantara Livestock Ship. Cow distribution chain that uses transportation The Camara Nusantara cattle ship has three distribution models. The most efficient distribution model is through breeders, cattle fattening companies, slaughterhouses, and consumers.

Keywords: job design, kleder, livestock, transportation
\end{abstract}

\begin{abstract}
Abstrak (Indonesia): Tujuan penelitian ini untuk menganalisis dan merancang desain pekerjaan kleder pada transportasi sapi di Kapal Ternak Camara Nusantara. Penelitian ini menggunakan metode analisis deskriptif kualitatif dengan melakukan observasi, dokumentasi, studi pustaka, dan wawancara langsung terhadap obyek yang diteliti dilapangan. Data primer diperoleh dari pelaku utama dan data sekunder melalui observasi, dokumentasi, dan studi pustaka. Desain kerja dirancang dengan mengikuti pendekatan Mader-Clark dan rantai distribusi sapi disajikan dalam bentuk bagan alir. Berdasarkan hasil penelitian ini menunjukkan bahwa kleder di Kapal Ternak Camara Nusantara belum memiliki desain kerja dan belum menerapkan deskripsi pekerjaan serta spesifikasi pekerjaan yang dibutuhkan. Hal ini ditunjukkan dengan tidak ada standar kompetensi kerja yang dijadikan sebagai pedoman kerja sehingga kleder tidak melakukan tugas sesuai dengan tugas dan wewenangnya di atas Kapal Ternak Camara Nusantara. Rantai distribusi sapi yang menggunakan transportasi Kapal ternak Camara Nusantara memiliki tiga model distribusi. Model distribusi yang paling efisien adalah melalui rantai peternak, perusahaan penggemukan sapi, rumah potong hewan, dan konsumen.
\end{abstract}

Kata kunci: desain kerja, kleder, ternak, transportasi

\section{Introduction}

The governments try to support the distribution of livestock in Indonesia by implementing the sea toll program. The sea toll program is a program implemented to strengthen the logistics system through waterways in Indonesia. The Camara Nusantara Livestock Cattle Ship is part of the implementation of the sea toll program to increase cattle distribution from central regions of beef cattle such as NTB, NTT, and South Sulawesi [1]. Based on previous research [2], it shows that the mechanism of live livestock transportation using Camara
Nusantara Cattle Ship is more effective than conventional transportation systems. Costs, time of delivery and weight loss of cattle at the destination and the amount of the cost and number of chains are more efficient.

Comparison of transportation mechanisms between cattle ship and conventional transportation shows that transportation by Camara Nusantara Cattle Ship shortens travel time from one and a half months to one week. Decreasing costs from IDR $1,500,000$ to IDR $1,100,000$ reduced weight loss for 
livestock ( $22 \%$ to $5 \%$ ) and cut supply chains from 13 points to 4 points [2]. However, the role of human resources in the Camara Nusantara Cattle Ship has not been maximized, especially kleder. Kleder is a cattle worker who is in charge of raising cattle during transportation of cattle in the Camara Nusantara Cattle Ship. The role of kleder in the Camara Nusantara Cattle Ship is very important because it deals directly with livestock on board.

Based on literature studies, during the transportation process weightloss and death still occur in livestock. This is related to the performance of the kleder on the ship. The quality of human resources (HR) must be improved to optimize service and efficiency of the livestock transportation system in Camara Nusantara Cattle Ship. For example, the capacity of the Camara Nusantara Cattle Ship is 500 cows with a crew of 30 people while the MV Ocean Ute is \pm 4000 cows with crew 36 [3]. This shows that the ratio of Camara Nusantara Cattle Ship crew with manageable livestock is 1:15 compared to the ratio of the MV Ocean Ute Ship crew from Australia to around 1: 111 head of cattle. The amount of HR that is not balanced with work productivity will add transportation cost during the voyage. The absence of a work description that is used as a guideline for working the kleder causes the task not to be carried out optimally and at the risk of endangering oneself and livestock on the Nusantara Camara Cattle Ship. In addition, the lack of awareness of the importance of the role of HR, especially the role of farmers also has an impact on livestock performance and welfare [4].

Job design is needed in the form of a job description and work qualifications for the kleder so that it can help improve the performance of the kleder in the Camara Nusantara Livestock Ship. In addition, the distribution chain of livestock through the Nusantara Camara Livestock Ship also needs to be identified to find out the limits of the working kleder.

\section{Material and Methods}

Primary data was collected through observation and interviews. In addition, secondary data was obtained from books and literature.

\subsection{Observation}

Observation was carried out by making careful observations and systematic recording [5]. Livestock [8]. The use of the OIE and ASEL standards was done because Indonesia does not have a fixed standard regarding the transportation of livestock with cattle vessels. Based on these
Observations were made by coming directly to the location to be used as the research location. Observations were carried out at Camara Nusantara Cattle Ship and Tanjung Priok Port.

\subsection{Interview}

The interview was conducted by getting answers from respondents on a one-sided demanding way because the request was only submitted by the evaluation subject [5]. Interviews were conducted with workers at Camara Nusantara Cattle Ship. Interviews were conducted for workers and experts using the on job interview method and sheet job and activities time filling.

\subsection{Job Analysis}

The steps taken in job analysis are based on Dessler [6]. Data collection was conducted to collect relevant basic information such as organizational charts, charts process, and job descriptions. The job analysis was conducted by collecting work activity data, required employee behavior, work conditions, nature and abilities humans needed to do the work. Verify information on job analysis to workers who doing the work and with the direct supervisor of the worker. Make job descriptions and job specifications.

\section{Result and Discussion}

There were several findings that indicate that there was not maintenance management standard that is used as a guideline for animal care during shipping. These findings were collected based on interviews and observations during the research. (Table 1).

At present, Indonesia refers to the OIE standards [7] and Australian Standard for the Export of The job design was carried out by interviewing the kleder to find out the job description for the kleder on the Camara Nusantara Cattle Ship. The job design was done by compiling the work plan according to the results of interviews with kleder and related stakeholders such as the NTT Provincial Livestock Service Office, NTT Province Animal Quarantine, PT Pelni, and PT Pelni Kupang. The job design was prepared based on the tasks and activities carried out by the kleder during the process of cattle transportation on the Camara Nusantara Cattle Ship standards, handling livestock during shipping was divided into two parts, namely, loading and unloading and management of livestock handling during shipping on cattle vessels [8]. 
Table 1 The summary of competencies of human resources in cattle supply chain

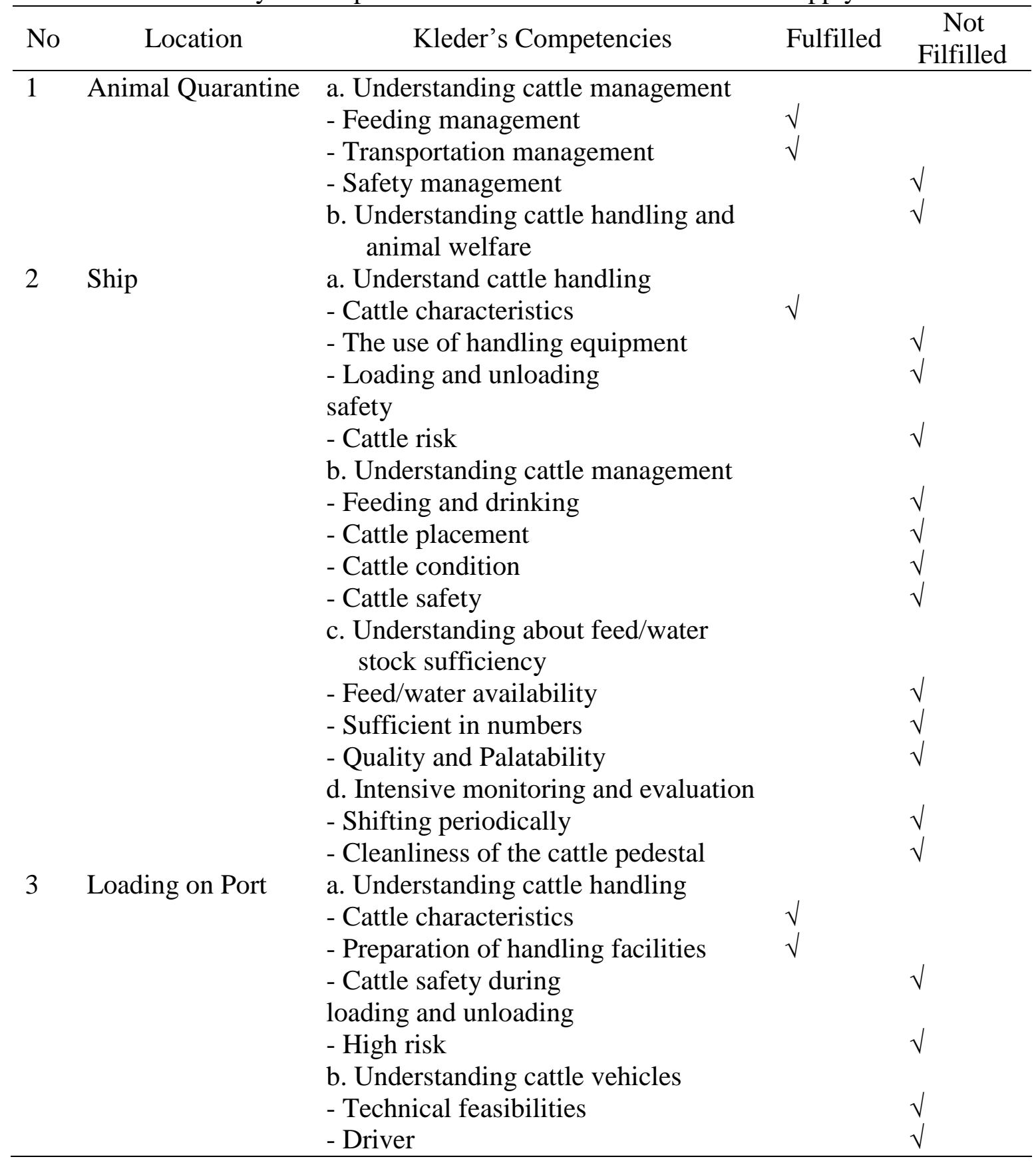

Interviews and observations that have been made show that most of the standards available on ASEL are not carried out by Kleder. Such as feeding management, bedding management, livestock grouping, and feed storage management. The food provided did not meet the needs during the voyage so that on the last day of the voyage there are several cows that do not get feed. In addition, feeding is also irregular. During the trip cattle are fed 1 or 2 times a day without considering the feed requirements per animal. The feed given was only manually cut corn straw and given enough to the livestock. Bedding management is not done for three days at the beginning of the cruise; this causes the cage floor to become wet, dirty, and filled with cow feces. The impact of many of these bedding management effects is magnified by any external increase in deck wetbulb temperatures, which can lead to, heat stress in livestock complicated by a deteriorating manure pad, deterioration of the manure pad resulting in decreased levels of hygiene and increased risks of infection associated with lameness and abrasions, and increased ammonia emissions causing health risks to both livestock and crew [8].

Grouping livestock is not based on age or body weight, only based on the order of the animals that enter the ship. Grouping strategy will impact the cow's ability to express aggressive eating behavior. Within a group of cattle, social hierarchy, competition for feed, water, space, and feed 
availability will determine feeding behavior and DMI [9]. In addition, feed storage management is not done properly. Feed is only stacked in the corner of the cage or in the middle of the road between the cages without any feed storage treatment to prevent damage to feed. Temperature and conditions of damp cages will cause food damage during the trip, besides improper storage of feed will trigger fungal growth and changes in the composition of forage feed [10].

Other findings indicate that the kleder who served at the time of observation had a low educational background, namely, elementary or middle school. This will affect the competencies possessed by the ledger. Everyone knows the handling of livestock is only based on the experience of raising livestock at home. This shows that the human resource who becomes the leader has not fulfilled the qualifications as a kleder who can handle the animals on board according to the standards that are referred to.

The job design of the kleder is carried out based on the findings obtained during the observation and refers to the competency requirements of the matched with ASEL.The format job design is based on Mader and Clark with modification as an alternative job design for the kleder on Camara Nusantara Cattle Ship [11]. The Job design consists of information on the summary of the work of the kleder, the essential function of the job, the qualifications and needs of the work consisting of education, knowledge needs, training needs, and experience, as well as mental and physical needs. The main work of the kleder is handling livestock during the livestock quarantine hall, the process of loading and unloading livestock on cattle vessels, and handling livestock during transportation in the Camara Nusantara Cattle Ship.

Tabel 2 Framework for the job of the kleder

\section{KLEDER JOB DESIGN FRAMEWORK}

\section{Position: Kleder / Ship Animal Worker}

\section{JOB SUMMARY}

Caring for and maintaining livestock from quarantine, loading and unloading processes, and during livestock transportation in the Camara Nusantara Cattle Ship.

\section{ESSENTIAL FUNCTIONS}

1. Unloading livestock at the quarantine hall, loading and unloading on the Camara Nusantara Cattle Ship

2. Weighing the weight of livestock before loading on the ship

3. To weigh cattle body weight after the loading process on the ship

4. Calculate feed and water requirements for livestock during quarantine and transportation

5. Carrying out and storing animal feed on the ship

6. Prepare and provide feed and drink to livestock during quarantine and sea transportation

7. Dealing with livestock contamination / dirt during the transportation process on cattle vessels

8. Record the number of livestock and livestock conditions during the process of quarantine and sea transortation

9. Implement animal health care together with veterinarians

10. Record and report on every incident during the quarantine and cattle transportation period

11. Maintain hygiene and health of livestock, including cleaning dirt and bathing livestock.

\section{JOB NEEDS AND QUALIFICATIONS}

1. Education: High School / Diploma in Animal Husbandry

2. Knowledge Needs: Knowing the techniques of raising livestock properly, mastering livestock handling techniques, having experience in raising livestock or having worked in the field of animal husbandry will be a plus.

3. Needs of skills and abilities: Leadership and capable of working with environmental conditions on board, being able to work with colleagues, communicate well.

4. Experience: Having experience in farming or not.

\section{OTHER INFORMATION}

1. Willing to work on cattle ship during the shipping process

2. Having physical and physical health

3. Strong mentality

4. Accustomed to working in the field

5. Schedule of departure of livestock with cattle boats can change 
The main function of the kleder designed based on observations is to carry out cattle handling in the quarantine hall, the process of loading and unloading cattle on the ship. Before and after transportation is carried out, kleder is responsible for weighing cattle cattle weight, calculating and preparing animal feed needs during transportation and storing animal feed properly, maintaining livestock conditions from dirt and bedding management, recording livestock conditions, and implementing livestock health maintenance together with the veterinarian on the ship. Summary of job description can be seen in The flow of cattle in the supply chain model above is divided into three chains, as follows:

1) Chain Structure 1

Farmer - Middleman - Feedlot Industry - RPH Consumer

Farmers sold their cattle to collectors who would take the cattle to the port for sale. Based on observations, collectors did not wait for farmers to deliver their livestock, but the middleman would be actively involved in finding the animals for efficiency in time and cost, then looking for prospective buyers who are part of cattle companies in Kupang, NTT. Cattle were shipped to Jakarta using Camara Nusantara Cattle Ship, and distributed to feedlot industries in Jakarta. Cattle were kept for body weight recovery or fattening before going to slaughterhouse. The follow up process involved cutting, packaging and delivery or sold to markets and consumers.

2) Chain Structure 2

Farmers - Feedlot Industry - RPH - Consumers There were also some farm owners who attempted feeding their cattle to meet the market weight and did
Table 2. Framework for the design of the work kleder.

The distribution structure of cattle in Indonesia is generally by land, sea, or by land-sea route. The operation of the Camara Nusantara Cattle Ship has shortened cattle distribution channels and reduced travel costs [3]. The distribution model of cattle with Camara Nusantara Cattle Ship, in East Nusa Tenggara Province follows the pattern as presented in Figure 1 Model of cattle distribution from NTT Province to consumers in Jakarta.

not sell their cattle to collectors neither waiting for collectors to buy their animals. Farmer bought the cattle from other farmers with low prices and did the fattening to reach the market weight before selling those animals to prospective buyers. This practice reduce the channel of middleman.

3) Chain Structure 3

Farmers - Feedlot industry and middleman Middleman in Jakarta - Cattle fattening company $\mathrm{RPH}$ - Consumers

Cattle collected from farmers were kept by collectors or hold by feedlot industries in NTT for some times. These structure involved two channels in NTT and three channels in Jakarta (Middleman-cattle fattening companies-RPH), then the cattle were sent to slaughterhouse around Jabodetabek before reaching the final consumers. This type of distribution system has some advantages such as quota assurance and risk management in the industry. There were also, however, some disadvantages as of consequences of channels involved, included the increase product prices (meat) in the beneficiary target i.e. consumers.

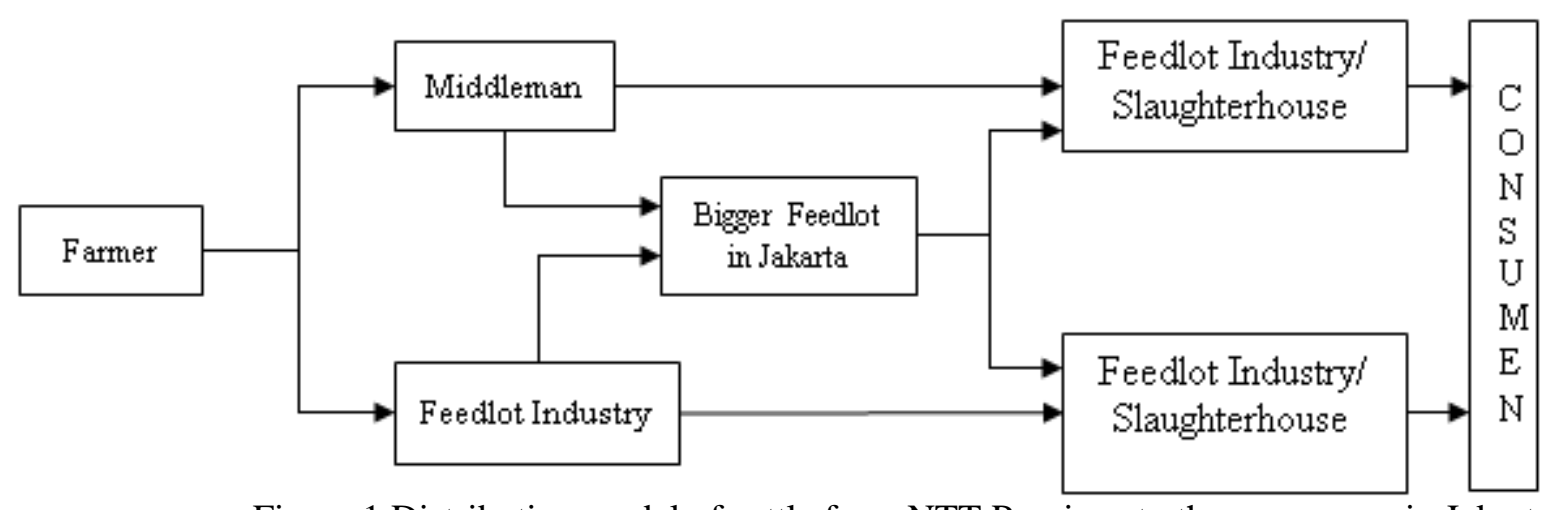

Figure 1 Distribution model of cattle from NTT Province to the consumers in Jakarta

Based on the three chain structures, chains 1 and 2 will be more efficient because they do not go through more collectors in Jakarta. It is seen that the largest total marketing chain is in the distribution structure number 3, namely, cattle fattening companies and middleman in Jakarta - cattle fattening companies - RPH - consumers. This certainly will not benefit consumers because it will cause the price of meat in consumers to be higher than the price of meat in the number 1 and number 2 chain structures without the need to conduct transactions with other middleman in Jakarta. If farmers can directly relate to prospective buyers in Jakarta, this will certainly increase the potential of 
margin that can be obtained by farmers while reducing the price of meat in consumers. This is an opportunity for farmers to be able to improve communication activities with prospective buyers without having to rely on middleman. Based on the distribution chain, the limit of the working kleder only starts from the farmer to the cattle fattening company.

\section{Conclusion}

The kleder who works in the Camara Nusantara Cattle Ship does not have a job description during the transportation process from the farmer to the fattening/slaughterhouse company in Jakarta. Job descriptions are only obtained based on work directives by livestock owners and ship operators. The absence of work descriptions as work standards causes the lack of capabilities needed to carry out their work so that the work obtained is not optimal or not in accordance with the standards. The job design was carried out to make work standards in the form of job descriptions and job specifications with details of essential functions, job qualification requirements, and additional supporting information for the kleder who would work on the Nusantara Camara Cattle Ship.

\section{Acknowledgement}

The author would like to thank all members of Department of Animal Production and Technology, including the technicians and lecturers for their continuous guidance, help and support given throughout the project of Animal Logistic Indonesia and Netherlands (ALIN). Special thanks are due to ALIN, for their help on financial support in the project.

\section{References}

[1] Direktorat Jenderal Peternakan dan Kesehatan Hewan. Pedoman Pelaksanaan Tata Niaga Ternak Melalui Transportasi Laut tahun 2017.
Jakarta, ID: Direktorat Jenderal Peternakan dan Kesehatan Hewan, 2017.

[2] A. Haryana and Y Nuryati."Peran Kapal Ternak dalam Memperlancar Distribusi dan Menekan Biaya Logistik Daging Sapi dari Sentra Produsen ke Sentra Konsumen di Indonesia". Jurnal Pusdiklat Perdagangan, vol. 2, pp 78 - 85, Jul 2016.

[3] Wellard. Wellard Annual Report 2018. Perth, AUS: Wellard Ltd, 2018.

[4] P.H. Hermsworth and G.J. Coleman. HumanLivestock Interaction Second Edition: The stockperson and the Productvity and Welfare of Intersvely Farmed Animals. Chippenham, UK: CAB Internayional, 2011.

[5] S. Arikunto. Dasar-dasar Evaluasi Pendidikan. Jakarta, ID: Bumi Aksara, 2007.

[6] G. Dessler. 2006. Human Resource Management $10^{\text {th }}$ Edition. Toronto, CA: Pearson Prentice Hall, 2006.

[7] World Organisation for Animal Health (OIE). Terrestrial Animal Health Code. Paris, FR: World Organisation for Animal Health (OIE), 2011.

[8] Australian Government Department of Agriculture, Fisheries and Forestry. Australian Standards for the Export of Livestock and Australian Position Statement on the Export of Livestock. Canberra, AUS: The Australian Government Department of Agriculture, Fisheries and Forestry, 2011.

[9] R.J. Grant and J.L. Albright. "Effect of animal grouping on feeding behavior and intake of dairy cattle". Journal of dairy science, vol. 84, pp E156-E163, 2001.

[10].W. Hall. Handling and storage of food grains in tropical and subtropical areas. Rome, IT: Food and Agriculture Organization of the United Nations, 1970.

[11] M. Mader-Clark. The Job Description Handbook. New York, US: Nolo, 2006. 